\title{
WAYANG PRESIDEN: MEDIA PENANAMAN NILAI KARAKTER DAN PENINGKATAN HASIL BELAJAR SISWA SEKOLAH DASAR
}

\author{
Sutaryanto* \\ Universitas PGRI Madiun \\ Jl. Setia Budi No. 85 Madiun, Jawa Timur, Indonesia
}

\begin{abstract}
ABSTRAK
Wayang merupakan peninggalan leluhur yang telah diakui UNESCO sebagai Masterpiece of Oral and Intangible Heritage of Humanity. Wayang diakui sebagai karya agung karena wayang mempunyai nilai tinggi bagi peradapan umat manusia. Media pembelajaran wayang presiden digunakan untuk menanamkan nilai karakter dan meningkatkan hasil belajar siswa kelas 4 di SDN 2 Grogol kecamatan sawoo kabupaten Ponorogo. Bentuk penelitian ini adalah Penelitian Tindakan Kelas (PTK) yang terdiri dari 2 siklus. Setiap siklus terdiri dari perencanaan, pelaksanaan tindakan, observasi, dan refeksi. Teknik pengumpulan data yang digunakan adalah observasi, tes dan angket. Penelitian ini diuji dengan menggunakan triangulasi sumber dan triangulasi teknik. Hasil penelitian yang dilaksanakan dapat disimpulkan bahwa penggunaan media wayang presiden efektif dalam menanamkan nilai karakter bangsa dan dan meningkatkan hasil belajar siswa siswa sekolah dasar.
\end{abstract}

Kata Kunci: Wayang presiden, karakter, hasil belajar

\begin{abstract}
Puppet is a relic ancestor had been recognized UNESCO as a Masterpiece of Oral and Intangible Heritage of Humanity. It is recognized as a masterpiece because it has a high value for the human civilization. Media puppet learning president used to imprint the value of a character and improve learning outcomes of the students in Grade 4 of State Primary School of sawoo, Ponorogo regency. This research used the classroom action research whit tho cycles. Each cycle consisted of four phases, namely: planning, implementation, observation, and reflection. The data of the research were gathered through observation, test and question form. This research tested by using source triangulation and technique triangulation. The results of the research carried out can be concluded that the use of media puppet president effective to infuse the value of a character the nation and improve learning outcomes primary school student.
\end{abstract}

Keywords: Puppet President, character, learning outcomes

\section{PENDAHULUAN}

Undang-undang No. 20 tahun 2003 Bab II pasal 3 menjelaskan bahwa tujuan dari pendidikan nasional pada dasarnya menjadikan manusia yang memiliki iman dan taqwa kepada Tuhan YME, serta memiliki akhak yang mulia, sehat, memiliki ilmu, cakap, kreatif, mandiri, dan menjadi warga yang demokratis dan bertanggung jawab. Sesuai dengan amanat dalam sistem pendidikan nasional dapat diambil kesimpulan bahwa pendidikan tidak hanya berperan dalam mencerdaskan warga negara,

\footnotetext{
* Penulis Koresponden

E-mail address: sutaryanto@unipma.com doi:
}

akan tetapi pendidikan harus dapat membentuk akhlak atau karakter manusia. Sehingga terwujudnya bangsa yang bermartabat yang sesuai dengan cita-cita UUD 1945.

Pendidikan tidak hanya membekali siswa dari aspek pengetahuan, tetapi pendidikan harus dapat membentuk manusia menjadi pribadi yang baik, yang memiliki budi pekerti yang luhur. Tantangan pendidikan sekarng ini adalah pembentukan karakter pada peserta didik. Adanya globalisasi memberikan dampak yang luar biasa bagi perkembangan hidup manusia. Manusia dimanjankan adanya kemajuan

Copyright@2017 Jurnal Artefak e-ISSN: 2580-0027 
teknologi yang serba cepat dan instan. Manisia menjadi lebih konsumtif, dan kurang memiliki sosial yang baik. Hal ini merupakan ancaman serius bagi keberlangsungan NKRI.

Pendidikan merupakan pemegang garda terdepan untuk menghadapi ini. pendidikan pendidikan terkait dengan pelaksana pembelajaran yaitu yang dilakukan seorang guru. Guru hendaknya dapat mentrasformasi pengetahuan dan penanaman karakter pada siswa. Guru tidakhanya dapat membekali siswa dari aspek pengetahuan akan tetapi guru juga harusdapat membekali siswa dengan pendidikan karakter positif. Salah satu penentu keberhasilan suatu pembelajaran adalah adanya media yang disajikan oleh seorang guru dalam membantu pembelajaran di kelas. Oleh karena itu seorang guru hendaknya memiliki pemahaman yang cukup tentang media pembelajaran (Hamalik, 1994: 6) yaitu memahami media untuk komunikasi pembelajaran yang mengefektifkan proses belajar mengajar, 2) memahami media dapat berfungsi dalam mencapai tujuan pendidikan, 3) seluk-beluk proses belajar, 4) mengatahui hubungan metode mengajar dan media pendidikan, 5) Memahami manfaat media dalam pengajaran, 6) guru memahami cara memilih dan menggunakan media pendidikan, 7) guru memahami berbagai jenis alat dan teknik media pendidikan, 8) guru memahami media dalam setiap jenis pembelajaran yang ingin disampaiakan dan 9) guru mampu melakukan inovasi media pendidikan.

Sehingga dapat ditarik kesimpulan bahwa media merupakan bagian yang tidak dapat dipisahkan dengan pembelajaran yang dilakukan oleh guru dalam mencapai tujuan pembelajaran di sekolah pada khususnya. Menurut Hamalik, penggunaan media pembelajaran yang tepat dengan materi pembelajaran dapat membvangkitkan minat dan motivasi siswa dalam proses pembelajaran (Arsyad, 2010). Salah satu media pembelajaran yang bias diterapkan dalam proses pembelajaran adalah media Wayang.

UNESCO telah mengakui wayang sebagai Masterpiece of Oral and Intangible Heritage of Humanity ('Karya-karya Agung Lisan dan Tak Benda Warisan Manusia'). Wayang merupakan salah satu peninggalan yang memiliki nilai luhur bagi peradapan umat manusia. Wibisono (2009) menjelaskan bahwa UNESCO menetapkan wayang sebagai karya Agung dunia di Paris pada tanggal 7 November. Dengan demikian wayang merupakan warisan budaya leluhur yang telah diakui dunia secara internasional yang memiliki nilai nilai bermanfaat bagi kehidupan masusia.

Media wayang sangat diperlukan seorang guru dalam pembelajaran di kelas yaitu sebagai media penanaman karakter kepada siswa. Wayang digunakan sebagai media pembalajaran dikelas untuk menyampaikan materi kehidupan Presiden. Wayang Presiden di desain dengan kariketur yang terbuat dari kertas kardus yang berwujut tokoh Presiden. Livien an lentz menjelaskan bahwa media wayang yang berbentuk kartun dapat mengarahkan siswa untuk berkomunikasi, membangkitkan emosi, dan sikap siswa, memperlancar dalam mencapai tujuan pembelajaran dan mengingat informasi yang disampaikan oleh seseorang dan membantu memahami teks bagi siswa yang lemah dalam membaca (Ngadino, 2009).

Berdasarkan hasil Observasi awal di SDN 2 grogol memiliki permasalahan dalam pembelajaran pada mata pelajaran Pendidikan Kewarganegaraan. Guru kurang mampu membuat media pembelajaran untuk menanamkan karakter bangsa kepada siswa kelas 4 di SDN gerogol. Selain itu nilai siswa pada mata pelajaran Pendidikan Kewarganegaraan mengalami penurunan. Perolehan nilai siswa dari batas KKM > 70 hanya diperoleh ketuntasan dengan persentase $56 \%$, itu menunjukkan hasil belajar siswa masih rendah. Hal ini salah satunya dikarenakan belum adanya media pembelajaran yang tepat yang telah dilakukan guru dalam pembelajaran dikelas. Berdasarkan permasalahan tersebut penulis mengadakan penelitian tentang penerapan media wayang Presiden sebagai media pembelajaranyang dapat menanamkan karakter bangsa dan mampu meningkatkat hasil belajar siswa di Sekolah dasar. Sehingga dapat memberikan solusi dari masalah yang di hadapi guru dalam melakukan pembelajaran di kelas.

\section{METODE PENELITIAN}

Penelitian yang dilakukan di kelas 4 SD Negeri 02 Grogol, ponorogo dilakukan pada tahun ajaran 2016/2017. Jumlah subjek penelitian ini berjulmlah 20 siswa yang terdiri dari 8 siswa laki-laki dan 12 siswa perempuan. Prosedur penelitian yang dilakukan terdiri 4 tahap berdasarkan Arikunto, dkk (2009:74) yaitu perencanaan (planning), pelaksanaan tinda-kan (action), observasi (observation), dan refleksi (reflecting). Penelitian ini bersumber pada data primer yaitu guru kelas dan siswa kelas 4 SD 
Negeri 02 Grogol. Sumber data sekunder adalah dokumentasi dan hasil observasi. Selain itu sumber data berasal dari arsip-arsip kelas dan informasi lainnya. Teknik pengumpulan data yang digunakan meliputi wawancara, observasi, tes, Angket, dan dokumentasi.

Teknik analisis yang digunakan dalam penelitian ini adalah:

1. Analisis data hasil observasi penanaman karakter menggunakan panduan dari Indarti (2008: 76) dengan rumus:

$$
P=\frac{F}{N} \times 100 \%
$$

Keterangan:

$\mathrm{P}=$ Persenrase aktivitas siswa atau guru

$\mathrm{F}=$ Banyaknya aktivitas guru atau siswa

$\mathrm{N}=$ Jumlah aktivitas keseluruhan

Setelah itu akan dinyatakan dengan kriteria yang bersifat kualitatif yaitu:

$80 \%-100 \%=$ Sangat Baik (A)

$66 \%-79 \%=$ Baik (B)

$56 \%-65 \%=$ cukup (C)

$40 \%-55 \%=$ Kurang (D)

$0 \%-39 \%=$ Sangat kurang $(\mathrm{E})$

Untuk menganalisis data hasil belajar belajar, peneliti menganalisis data secara kuantitatif dengan menggunakanpanduan dari Djamarah (2005:302) dengan rumus: Rata-rata kelas.

$M=\frac{\sum X}{N}$

Keterangan:

$\mathrm{M}$ = rata-rata kelas

$\sum \mathrm{X}=$ jumlah nilai total yang diperoleh dari hasil penjumlahan nilai tiap

$\mathrm{N} \quad=$ Jumlah seluruh siswa

2. Data angket respon siswa terhadap pengguna media wayang presiden di dengan menggunakan panduan dari Arikunto (2009:

245) dengan rumus:

$P=\frac{\sum A}{B} X 100 \%$

Keterangan:

$\mathrm{P}=$ persentase respon siswa

$\frac{\sum A}{B}=$ Jumlah pemilih jawaban yang sama

$\mathrm{B}=$ Banyaknya siswa (responden)

Setelah itu akan dinyatakan dengan kriteria yang bersifat kualitatif yaitu kriteria : $80 \%-100 \%=$ Sangat Baik $(A)$
$66 \%-79 \%=$ Baik (B)

$56 \%-65 \%=$ Cukup (C)

$40 \%-55 \%=$ Kurang (D)

$0 \%-39 \%=$ Sangat kurang $(\mathrm{E})$

Penelitian ini menggunakan uji validitas triangulasi, sumber, dan triangulasi teknik.

\section{HASIL PENELITIAN DAN PEMBAHASAN}

\section{Hasil Penelitian}

Pelaksanaan Tindakan Siklus I

1. Perencanaan (planning) yang dilakukan pada satah ini adalah membuat Rencana Pelaksanaan Pembelajaran (RPP) sebagai acuhan guru dalam melaksanakan pembelajaran. Kemudian membuat media Wayang Presiden digunakan sebagai media pembelajaran. Selanjutnya menysusun soal tes dan kunci jawaban tes. Soal tes digunakan untuk mengukur hasil belajar siswa. Tes yang diberikan berbentuk soal pilihan ganda yang diberikan pada akhir siklus. Menyusun dan menyiapkan lembar observasi pembelajaran sebagai alat untuk mengukur ketercapaian guru dalam menanamkan karakter pada siswa.

2. Tindakan (Action)

Pelaksanaan tindakan pada siklus I dilakukan sebanyak dua kali pertemuan. Pelaksanaan tindakan dilakukan guru sesuai dengan yang tercantum dalam RPP. Rencana Pelaksanaan pembelajaran yang dilakukan guru harus sesuai dengan langkah-langkah penerapan media Wayang Presiden dalam penanaman karakter kepada siswa. Dalam hal ini peneliti melakukan kegiatan observasi. Kegiatan pelaksanaan tindakan ini diakhiri dengan pengukuran hasil belajar siswa melalui tes. Adapun urutan proses yang dilakukan dalam proses pembelajaran adalah:

a. guru memperkenelkan karakter tokohtokoh wayang presiden, dan dilanjutkan dengan

b. guru bercarita wayang didepan kelas. Cerita yang dipilih harus sesuai dengan meteri pembelajaran. Materi pembelajaran diawali dengan biografi masing-masing presiden dan dilengkapi peristiwa-peristiwa semasa presiden menjabat. Misalnya pada masa presiden Soekarno ada peristiwa kemerdekaan Indonesia, isi materi itu disampaikan guru dengan media wayang presiden Soekarno. 
c. Bahasa pada saat bercerita yang digunakan pentas bukan bahasa sastra jawa seperti dalam pentas wayang kulit, akan tetapi bahasa yang digunakan adalah bahasa Indonesia atau bahasa sehari-hari.

d. Guru juga dapat berperan sebagai sutradara, bertugas mengkoordinasi lalu lintas pertunjukan agar berhasil (Rinurbad, 2009: 1). Masing - masing wayang presiden dapat dipentaskan oleh siswa tidak hanya guru saja. Siswa yang membawakan tokoh wayang harus menghafal materi yang ingin disampaikan.

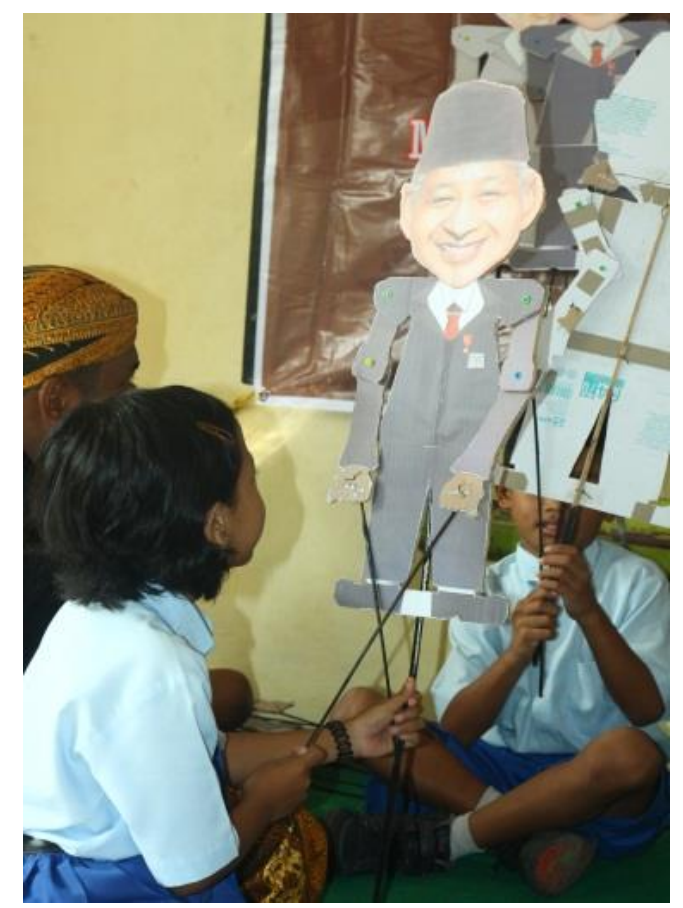

Gambar 1 Dokumentasi pribadi

e. Saat pementasan, jika perlu menggunakan ilustrasi music dan tata cahaya agar pentas wayang lebih "hidup". Musik bisa menggunakan mesin audio atau mungkin bisa menggabungkan kelompok karawitan, jika ada. Sekaligus siswa bisa lebih mengenal musik tradisional jawa, misal siswa jadi mengaerti tentang alat music yang bernama rebab, gender, gambang, siter, clempung, kendhang, suling, bonang, dan lainnya (Ferdiansyah, $2010: 37)$.

\section{Observasi (observation)}

Hasil pengamatan dilihat berdasatkan pengamatan dari siklus I pada pertemuan 1 dan 2. Hasil observasi diperoleh data observasi pelaksanaan guru dalam penanaman karakter melelui media Wayang
Presiden dan data observasi tes hasil belajar siswa. Berdasarkan hasil pengamatan kepada guru pada siklus I dari pertemuan 1 dan 2 diperoleh prersentase pelaksanaan penanaman karakter dengan media Wayang Presiden mencapai $75 \%$ dan $78 \%$, berdasarkan perolehan persentase tersebut dapat ditarik kesimpulan bahwa dalam pelaksanaan penanam karakter dengan media Wayang Presiden belum mencapai target yang telah ditentukan. Guru dalam penerapan media wayang presiden masih terlihat kaku karena belum terbiasa menerapkan media tersebut. Sedangkan untuk hasil data tes hasil belajar siswa pada siklus I pada pertemuan 1 dan 2 diperoleh data ketuntasan belajar mencapai persentase $68 \%$ dan $70 \%$ dari batas Kriteria Ketuntasan Minimal (KKM) adalah $\geq 70$. Hasil belajar siswa pada siklus I dapat disimpulkan bahwa hasil belajar belum mencapai batas persentase yang ditetapkan yaitu sebesar $85 \%$.

4. Refleksi (reflecting)

Refleksi siklus I dilakukan pembahasan mengenai hasil dam masalah yang dihadapi. Berdasarkan data pada siklus I guru belum terbiasa menggunakan media wayang presiden dalam pembelajaran dan hasil belajar siswa belum mencapai target persentase ketuntasan yang telah ditetapkan. Pada siklus ini siswa masih banyak bercanda belum memperhatikan isi materi dalam pembelajaran, sehingga materi belum dapat di pahami siswa secara baik yang berakibat kurangnya nilai hasil belajar siswa.

Keterbatasan waktu merupakan penyebab yang menjadi kendala dalam pelaksanaan siklus I. Siswa belum dapat melakukan simulasi secara individu dalam memeragakan media Wayang Presiden. Karena hasil pada sisklus I belum dapat mencapai dikator ketercapaian pada lembar observasi pada penanaman karakter dan capaian nilai hasil belajar belum memenuhi target persentase maka dilalukan penyempurnaan pada siklus yang ke II. Sebelum siklus II peneliti melaksanakan perbaikan terhadap permasalahan yang muncul. Permasalahan dari guru dalam penerapan terlihat guru belum terbiasa menggunakan wayang presiden diperbaiki dengan mengadakan diksusi dan pengarahan kepada guru dan mengulangi prosedur langkah-langkah penerapan wayang sebagai media penanaman karakter kepada siswa. Sedangkan untuk masalah waktu pelaksanaan yang memakan waktu terlalu lama 
dilakukan perbaikan dengan mendisiplinkan waktu dengan baik.

\section{Pelaksanaan Tindakan Siklus II}

\section{Perencanaan (Planing)}

Pelaksanaan perencanaan siklus ke II ini sama seperti pelaksanaan siklus I yang dilakuakan dengan penyusunan RPP yang dibuat dua kali pertemuan, mempersiapkan Media Wayang Presiden dan menyiapkan alat pengukuran data.

2. Tindakan (Action)

Pelaksanaan siklus II sama seperti pelaksanaan siklus I.

3. Observasi (Observation)

Berdasarkan hasil pengamatan kepada guru pada saat siklus II yang dilaksanakan sebanyak 2 kali pertemuan diperoleh prersentase pelaksanaan penanaman karakter dengan media Wayang Presiden mencapai $85 \%$ dan $98 \%$, dengan demikian dapat ditarik kesimpulan bahwa dalam pelaksanaan penanam karakter dengan media Wayang Presiden guru dapat melaksanakannya dengan baik. Akan tetapi pelaksanaan penanaman karakter yang dilaksanakan guru belum mencapai $100 \%$, hal ini dikarenakan waktu pelaksanaan tidak pembelajaran dengan media Wayang Presiden masih melebihi batas waktu kegiatan pembelajaran . Sedangkan hasil belajar siklus II yang dilaksanakan sebanyak 2 kali pertemuan yaitu pertemuan 1 dan 2 diperoleh data ketuntasan belajar mencapai persentase $86 \%$ dan $92 \%$ dari batas Kriteria Ketuntasan Minimal adalah $\geq 70$. Berdasarkan hasil belajar siswa pada siklus II dapat disimpulkan bahwa hasil belajar yang telah dicapai siswa telah mencapai batas persentase yang telah ditetapkan yaitu $85 \%$.

Karena siklus II hasilnnya telah memenuhi target, maka pada kegiatan akhir peneliti melakukan pengambilan data tentang respon siswa terhadap pembelajaran dengan penerapan Media Wayang Presiden. Hasil respon siswa mencapai 96\%, hal ini menunjukkan bahwa respon siswa sangat baik (A).

4. Refleksi (reflecting)

Pelaksanaan siklus II telah mencapai target, baik dari hasil capaian pelaksanaan penanaman karakter yang dilakukan oleh guru dan capaian hasil belajar siswa. Berdasarkan capaian tersebut, maka pelaksanaan siklus selanjutnya sudah tidak dilakukan.

Pencapaian hasil siklus I dan II dapat dilihat dengan jelas pada table berikut:

Tabel 3.1 hasil observasi penanaman nilai

\begin{tabular}{c|c|c} 
kertemuan & karakter \\
Siklus I & Siklus II \\
\hline 1 & $75 \%$ & $85 \%$ \\
\hline 2 & $78 \%$ & $98 \%$
\end{tabular}

Table 3.2 Hasil Observasi hasil belajar siswa

\begin{tabular}{c|c|c} 
Pertemuan & Siklus I & Siklus II \\
\hline 1 & $68 \%$ & $86 \%$ \\
\hline 2 & $70 \%$ & $92 \%$
\end{tabular}

Peningkatan hasil observasi penanaman karakter yang dilaksanakan guru dapat dilihat pada gambar diagram berikut:

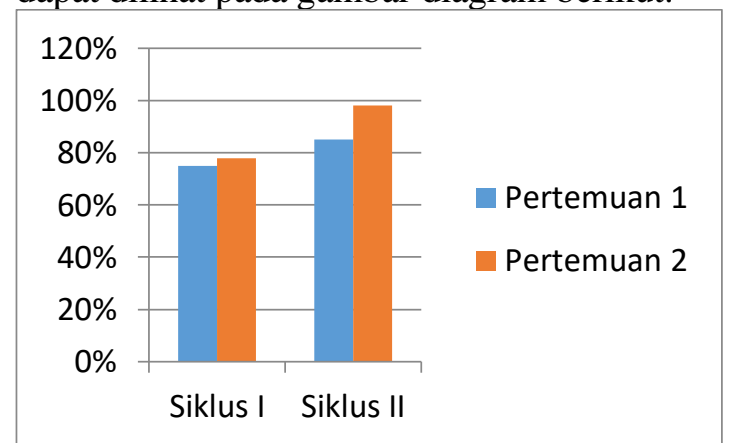

Gambar 3.1 Peningkatan penanaman karakter pertemuan 1

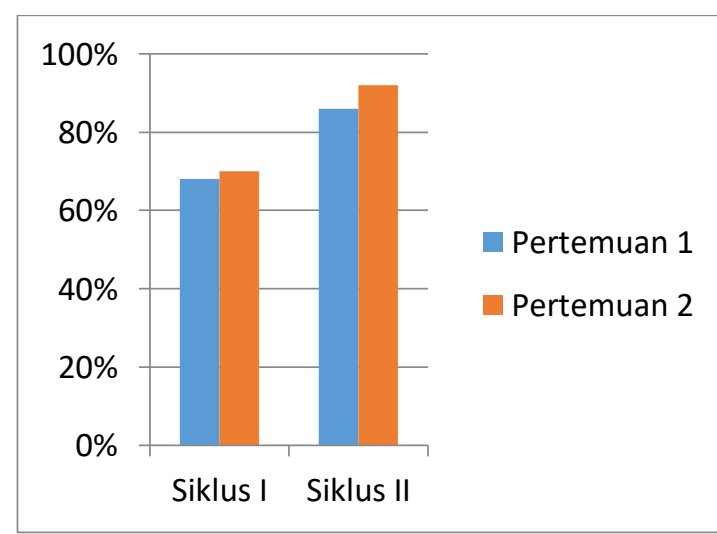

Gambar 3.1 Peningkatan penanaman karakter pertemuan 2

\section{Pembahasan}

Hasil pengamatan terhadap pelaksanaan observasi penanaman nilai karakter yang dilaksanakan oleh guru dengan menggunakan media wayang presiden dengan persentase siklus terakhir yaitu pada sisklus II mencapai $98 \%$. Hal ini menunjukkan bahwa pelaksanaan penanaman 
karakter dengan media wayang presiden dapat terlaksana dengan baik. Hal ini sesuai dengan pendapat Musfiqon (2012:35) fungsi media pembelajaran adalah meningkatkan efektivitas dan efesiensi pelaksanaan pembelajaran, mengefektifkan proses komunikasi dalam pembelajaran, meningkatkan kualitas pembelajaran. Sesuai dengan hal ini pada penerapan media wayang presiden dapat mempermudah guru dalam menanamkan nilainilai karakter kepada siswa.

Nurgiyantoro (2011) menjelaskan bahwa wayang merupakan karya agung yang mempunyai nilai tinggi bagi peradapan manusia. Wayang erat kaitanya dengan nilai, yaitu yang tercermin pada karakter tokoh, cerita, maupun dari berbagai unsur lain yang mendukung. Semua nilai yang tercermin dalam tokoh wayang dapat menjadi rujukan pengembangan karakter bangsa. Fajrie (2013) menjelaskan bahwa hasil belajar siswa kelas 4 SD Negeri 2 Gragol menunjukkan persentase pada temuan awal hanya sebesar $56 \%$. Setelah penerapan media wayang presiden hasil belajar meningkat pada siklus I temuan akhir hasil belajar siswa mencapai $70 \%$, dan dilanjutkan pada siklus II meningkat kembali dengan mencapai ketuntasan sebesar 92\%, berdasarkan tersebut maka siklus II telah mencapai kriteria ketuntasan yang telah ditetapkan dengan ketercapaian $85 \%$ dari persentase ketuntasan tang ditetapkan. Berdasarkan hasil yang telah di capai sesuai dengan pendapat Salamah (2017) dari hasil penelitiannya menjelaskan bahwa media wayang yang diterapkan dalam pembelajaran dapat meningkatkan hasil belajar siswa. Sedangkan perolehan hasil respon siswa mencapai 96\% yang dapat dikatakan mencapai kriteria sangat baik. Hal ini sesuai dengan Salamah (2017) yang menjelaskan bahwa respon siswa dengan pembelajaran menggunakan media wayang menunjukkan hasil respon sangat bagus, hal ini didasari dari hasil jawaban-jawaban siswa melalui pertanyaan-pertanyaan seputar media wayang.

\section{SIMPULAN}

Penelitian ini dapat disimpulkan bahwa media wayang presiden efektif dalam menanamkan nilai karakter kepada siswa sekolah dasar. Selain. Penanaman karakter dari pelaksanaan siklus I dan II menunjukkan peningkatan hasil yang sangat baik. Selain itu hasil belajar yang diperoleh siswa dari setiap siklus menunjukkan pertambahan peningkatan persentase. Respon siswa terhadap pelaksanaan pembelajaran dengan menggunakan media wayang presiden juga menunjukkan respon dengan kriteria sangat baik.

\section{DAFTAR PUSTAKA}

Arikunto, Suharsimi, dkk. 2009. Dasar-Dasar Evaluasi Pendidikan (Edisi Revisi). Jakarta: Bumi Aksara.

Arsyad, A. (2010). Media Pembelajaran. Jakarta: PT Raja Grafindo Persada.

Djamarah, Syaiful Bahri. 2005. Guru dan Anak Didik dalam Interaksi Edukatif: Suatu Pendekatan Teoritis Psikologis. Jakarta: Rineka Cipta.

Fajrie, N. (2013). Media Pertunjukkan Wayang Untuk Menumbuhkan Karakter Anak Bangsa. Diunduh pada 13-08-2017 pada laman:

https://publikasiilmiah.ums.ac.id/handle/ $11617 / 3486$

Ferdiansyah, Farabi. 2010. Kesenian Karawitan, Gamelan Jawa. Jogjakarta: Garailmu.

Hamalik, O. 1994. Media Pendidikan, Cet. VII. Bandung: PT Citra Aditya Bakti

Musfiqon. 2012. Pengembangan Media \& Sumber Pembelajaran. Jakarta: Prestasi Pustaka.

Ngadino, Y. (2009). Pengembangan Media Pembelajaran. Surakarta: Pendidikan Profesi Guru FKIP UNS.

Nurgiyantoro, B. 2011. Wayang dan Pengembangan Karakter Bangsa. Jurnal Pendidikan Karakter, 1(1).

Pemerintah Republik Indonesia. 2003. Undangundang Republik Indonesia Nomor 20 Tahun 2003 Tentang Sistem Pendidikan Nasional. Jakarta: Depdiknas.

Rinurbad. 2009. Ayo Bermain Teater. Cirebon: CV. Gunung Djati.

Salamah, E. R. (2017). Penggunaan Media Wayang Pada Pembelajaran IPS Materi Tokoh Tokoh Kemerdekaan Indonesia Untuk Meningkatkan Hasil Belajar Siswa Kelas V Sekolah Dasar.

Syaiful Bahri. 2005. Guru dan Anak Didik dalam Interaksi Edukatif: Suatu pendekatan Teoritis Psikologi. Jakarta: Rineka Cipta.

Wibisono, Singgih. 2009. Wayang, Karya Agung Dunia. Diunduh 01 Juli 2016, pada laman: http://www.Sastra-Indonesia.com/ 2009/12/Wayang, Karya Agung Dunia/. 